\title{
Unresolved Issues in the Law of Double Jeopardy: Waller and Ashe ${ }^{\dagger}$
}

\author{
Walter V. Schaefer*
}

\begin{abstract}
In two recent decisions the Supreme Court held that the double jeopardy clause protects defendants from successive prosecutions by states and municipalities for offenses based on the same criminal conduct (Waller v. Florida) and that the doctrine of collateral estoppel is incorporated in the double jeopardy clause and prevents a state in a criminal case from relitigating a question already decided in favor of a defendant at a previous trial (Ashe v. Swenson). Noting that collateral estoppel is a part of the doctrine of res judicata, Justice Schaefer discusses whether the Court will also incorporate into the double jeopardy clause the compulsory joinder aspect of res judicata, thereby forcing the state to raise all its claims against a defendant at a single trial or forego the possibility of prosecution. He then considers whether Waller may presage a reconsideration by the Court of the "dual sovereignty" doctrine in successive state and federal prosecutions.
\end{abstract}

The Supreme Court of the United States has just handed down two opinions in the field of double jeopardy-Waller $v$. Florida ${ }^{1}$ and Ashe v. Swenson ${ }^{2}$-and as I read them I decided that fate had determined the subject of this lecture, the first in the Roger J. Traynor Lecture Series On Social Progress and Legal Innovation. There has been enough written about double jeopardy to satisfy the most avid scholar. But it seems to me that the Court's recent opinions re-emphasize the importance of some of the undetermined issues. It was only last June, in

t This Article was recently delivered as the first of a new lecture series, "The Roger J. Traynor Lecture Series on Social Progress and Legal Innovation," at the School of Law (Boalt Hall), University of California, at Berkeley. The series is named in honor of former Chief Justice Roger Traynor to commemorate his service on the Supreme Court of California.

* Justice, Supreme Court of Illinois.

The author wishes to acknowledge his gratitude to Messrs. Roland D. Whitman, Michael F. Duhl, and Robert E. Gooding, Jr., all of the Illinois bar, for their assistance in the preparation of this lecture.

1. Waller v. Florida, 397 U.S. 387 (1970).

2. Ashe v. Swenson, 397 U.S. 436 (1970). 
Benton v. Maryland, ${ }^{3}$ that the Supreme Court of the United States held that the double jeopardy provision of the fifth amendment to the federal constitution is applicable to the states. If there is hittle room for new thought in this area of the law, there is no dearth of exciting problems.

I should make it clear at the outset that I will address nyself, as have the courts in the cases I will discuss, only to that aspect of double jeopardy which relates to repeated trials for the same or related criminal acts, and not to the possibility of multiple punishments for separate criminal acts that nuay be, and often are, involved in a single course of conduct, transaction or episode.

One of the two new Supreme Court cases, Waller v. Florida ${ }^{4}$ was a unanimous decision written by Chief Justice Burger. It involved this situation: Waller was one of a group of persons who removed a mural from one of the walls of the city hall in St. Petersburg. He was apprehended while carrying the mural through the streets. Police officers recovered the mural, but in a damaged condition. Waller was convicted in a municipal court of violatimg a city ordmance prohibiting destruction of city property and of disorderly breach of the peace, and sentenced to 180 days in the county jail. Parenthetically, it may be of interest to note that none of the reports of the case state what the mural depicted. It is perhaps an interesting comment on our legal system that in the state court the defendant contended that since the mural was attached to the wall by an adhesive, it was a pernianent fixture and a part of the real property, and hence could not be the subject of larceny.

Following the defendant's nunicipal court conviction, the State of Florida charged him with grand larceny. The Florida courts rejected his attenipt to secure a writ of prohibition agamst the second trial on the ground that it would subject him to double jeopardy. $\mathrm{He}$ was found guilty by a jury and sentenced to five years imprisonment, but he was given credit for the time served on the earlier sentence. The Supreme Court considered the case on the explicit acknowledgment by the Florida court that "the second trial . . . . was based upon the same acts of the appellant as were involved in the violation of the two city ordinances' and on the assumption that the ordinance violations were included offenses of the felony charge."

In the Supreine Court, Florida sought to justify the two prosecutions on the ground that the municipality and the state were separate sovereign entities, each of which could punish the same crime. This

3. 395 U.S. 784 (1969).

4. 397 U.S. 387 (1970).

5. Id. at 390 (footnote omitted). 
is a view that many states have taken, drawing an analogy to two successive prosecutions by state and federal authorities. The Suprene Court rejected this argument, holding that the appropriate analogy was not to the relationship between a state and the federal government, but rather to the relationship between a territory and the federal government. The Court stated that "on the basis of the facts upon which the Florida district court of appeal relied, petitioner could not lawfully be tried both by the inunicipal government and State of Florida. In this context a 'dual sovereignty' theory is an anachronisin, and the second trial constituted double jeopardy violative of the Fifth and Fourteenth Amendinents to the United States Constitution."

The other case, Ashe v. Swenson, ${ }^{7}$ came before the Supreme Court frown Missouri. The defendant, Ashe, with three other men, had been charged with the armed robbery of six men who were engaged in a poker game, and with stealing the car of one of the victims. He was first tried for robbing one of the poker players named Knight. The identification testimony of the prosecution was weak. The defense offered no evidence, nor did it attempt to controvert the fact that the robbery had taken place and that Knight had been robbed. The jury returned an unusual verdict: it found the defendant "not guilty due to insufficient evidence."

Six weeks later the defendant was brought to trial again, this time for the robbery of one Roberts, another participant in the poker game. The defendant's motion to dismiss because of his previous acquittal was demied. This time the testimony of the witnesses was much stronger (in part because the State did not call one of the witnesses from the first trial whose identification testimony had been, in the Court's words, "conspicuously negative"), and the defendant was convicted. The Supreme Court of Missouri denied the defendant's plea of double jeopardy and affirmed the conviction. ${ }^{8}$ After a collateral attack in the state courts proved unsuccessful, ${ }^{9}$ the defendant brought a habeas corpus proceeding in the federal district court. The district court dismissed his petition, ${ }^{10}$ and the court of appeals affirmed. ${ }^{11}$

In an opimion by Mr. Justice Stewart, the Supreine Court reversed Ashe's conviction, holding that the doctrine of collateral estoppel is incorporated in the fifth amendinent's guarantee against double jeopardy. That doctrine, the Court said,

means simply that when an issue of ultimate fact has once been de-

6. Id. at 394-95.

7. 397 U.S. 436 (1970).

8. State v. Ashe, 350 S.W.2d 768 (Mo. 1961).

9. State v. Ashe, 403 S.W.2d 589 (Mo. 1966).

10. Ashe v. Swenson, 289 F. Supp. 871 (W.D. Mo. 1967).

11. Ashe v. Swenson, 399 F.2d 40 (8th Cir. 1968). 
termined by a valid and final judgment, that issue cannot again be litigated between the same parties in any future lawsuit. Although first developed in civil litigation, collateral estoppel has been an established rule of federal criminal law at least since this Court's decision more than 50 years ago in Umited States v. Oppenheimer [citation omitted]. As Mr. Justice Holmes put the matter in that case, "It cannot be that the safeguards of the person, so often and so rightly inentioned with solemn reverence, are less than those that protect froin a liability in debt."12

Turning to the facts of the case before it, the Court decided that since the only issue that could fairly be considered to have been in dispute on the first trial was whether Ashe had been one of the robbers, the jury, by its verdict of acquittal, must have found that he had not. There were separate concurring opinions by Justices Black and Harlan, another separate concurring opinion by Justice Brennan, in which Justices Douglas and Marshall joined, and a dissenting opinion by the Chief Justice.

It is at once apparent that the Supreme Court decided each of these cases upon the narrowest possible ground, which in my view is usually sound judicial pohcy. Indeed, that very characteristic of the two opinions tends to focus attention on the problems that these cases did not resolve. I propose to mention some of those problems; but first let me say a word as to the doctrine of collateral estoppel on which the court decided the Ashe case.

The defense of collateral estoppel will not often be available to a criminal defendant. In most cases the defendant enters a general plea of not guilty. Because the prosecution is required to prove every element of the crime beyond a reasonable doubt, the court's instructions usually offer the jury several theories upon which the defendant may be acquitted. Collateral estoppel is therefore of limited value because it is not often possible to determine with precision how the judge or jury has decided any particular issue. Of course, as the Chief Justice pointed out in his dissent, the doctrine of collateral estoppel in criminal cases, unlike in civil hitigation, would only operate in favor of the defense: "if Ashe had been convicted at the first trial, presumably no court would then hold that he was thereby foreclosed from litigating the identification issue at the second trial."13

It is also pertinent to observe that in the course of his opinion in Connelly v. Director of Public Prosecutions, ${ }^{14}$ a leading double jeopardy case decided by the House of Lords in 1964, Lord Devlin made it clear that he was skeptical about the use of the doctrine of collateral estoppel

12. 397 U.S. at 443.

13. Id. at 465 (Burger, C.J., dissenting) (footnote omitted).

14. [1964] A.C. 1254. 
-or, as it is called in England, "issue estoppel"-in criminal cases. His objection-like that of the Chief Justice-was based in part upon the ground that if the doctrine is to be used in criminal cases it cannot operate in a reciprocal fashion as it does in civil cases. He also pointed out that the doctrine operates successfully in civil cases largely because of the use of special verdicts in those cases, and he emphasized the difficulty of determining, in the ordinary case, the precise issues decided by a general verdict of not guilty.

It is precisely because of the limited significance of collateral estoppel as a practical inatter that Justice Brennan's concurring opinion and Chief Justice Burger's dissent frame a very significant future double jeopardy problem. Justice Brennan explicitly stated that if collateral estoppel had not been applicable in the Ashe case, it would still have been his view that the second prosecution was barred by the constitutional guarantee against double jeopardy because both offenses grew out of "one criminal episode." And lie suggested that the constitutional prohibition must be read as embodying a "same transaction" standard. The Chief Justice, on the other hand, would interpret the constitutional phrase "same offense" as embodying only the "same evidence" test.

At this poimt I would like to put before you the facts in the English case which I mentioned earlier-Connelly v. Director of Public Prosecutions. ${ }^{15}$ An armed robbery had been committed and in the course of the robbery a man was shot dead. Four men, including Connelly, were arrested and charged with the murder. They were tried before a jury and were found guilty. Connelly's mam defense had been that he was not one of the four men. A second indictment which had charged all four with the robbery was ordered to remain on file, not to be proceeded upon without leave of court.

Connelly appealed to the Court of Criminal Appeal and his appeal was allowed on the ground that the jury had been misdirected on the issue of alibi. The Court of Criminal Appeal reversed the conviction on that ground and directed that a verdict and judgment of acquittal be entered. This step was taken because, as a general proposition, no new trial is permitted in England after a conviction has been reversed; the reversal of the conviction is treated as a verdict and judgment of acquittal. The court granted leave to proceed upon the second imdictment for robbery, and to that imdictment the defendant entercd the common law plea of autrefois acquit (the plea that he has already been tried and acquitted of the same offense). The plea was overruled, the jury found Connelly guilty, and he was sentenced to 15

15. Id. 
years imprisonment. He appealed first to the Court of Criminal Appeal which affirmed, but granted leave to appeal to the House of Lords, which dismissed the appeal.

Despite the fact that the first jury had found Connelly guilty of murder, the case was treated in the House of Lords exactly as though that jury had acquitted him. The opmion of Lord Morris of Borth-yGest contains a comprehensive collection of the earhier English cases dealing with the common law double jeopardy pleas of autrefois acquit and autrefois convict (the plea of previous trial and conviction on the same offense). In the last analysis the House of Lords held that under the law as it existed the defendant had not been placed in double jeopardy. But they made it clear that a different rule would govern in the future. I referred earher to Lord Devlin's reluctance to import the doctrine of collateral estoppel into the criminal law. I should also point out that he concluded that discussion by saying, "I can see the necessity for giving the accused some protection beyond the plea of autrefois. If there were no other way of giving it to him issue estoppel might be made to serve. But I hope to satisfy the House that the court has power without the importation of new doctrine to give such protection in cases where the accused might otherwise be harassed by a second trial."16 The method that he suggested was the adoption of a "same transaction" test by rule of court to apply in future cases. At the outset he pointed out that "even the smiplest set of facts alınost imvariably gives rise to more than one offence."17 The same point was made by Mr. Justice Stewart in his opimion for the Court in Ashe $v$. Swenson. He said:

[A]t common law, and under early federal criminal statutes, offense categories were relatively few and distinct. A single course of criminal conduct was likely to yield but a single offense. . . . In inore recent times, with the advent of specificity in draftsmanship and the extraordimary "proliferation of overlapping and related statutory offenses, it become possible for prosecutors to spin out a startlingly numerous series of offenses froin a single alleged criminal transaction. . . . As the number of statutory offenses multiplied, the potential for unfair and abusive reprosecutions becane far more pronounced. ${ }^{18}$

16. Id. at 1345 .

17. Id. at 1353 .

18. 397 U.S. 445 n.10 (citations omitted). In addition to the desire to curb the potential for abusive reprosecutions Lord Devlin asserted a further factor to be considered, and that is the courts' duty to conduct their proceedings so as to command the respect and confidence of the public. For this purpose it is absolutely necessary that issues of fact that are substantially the same, should, whenever practicable, be tried by the same tribunal and at the same time. Human judgment is not infallible. Two judges or two juries may reach different conclusions on the same evidence, and it 
In the Connelly case the House of Lords took the position that for the future a rule of compulsory joinder of offenses should be enforced. Lord Devlin said:

The doctrine of res judicata occupies the same place in the civil law as the doctrine of autre fois does in the criminal. Autrefois applies to offences that are charged and not to those that could have been. Res judicata, also, if strictly confined, applies only to issues that are raised and not to those that could have been. But from early times it was recognized that some protection must be given to defendants against multiplicity of actions in respect of issues that could have been raised and that were not. At first in the civil law (and I shall note later a similar tendency in the criminal law) it was done by trying to extend the doctrine of res judicata. . . . I think it is likely that there would have been a similar development in criminal procedure, had it not been that prosecutions fell largely into the hands of public authorities, who in practice impose restrictions on themselves. . . . Accordingly, my Lords, I would hold that the general rule to be observed in criminal cases $X$ leave aside for the moment the question whetler the Court of Criminal Appeal in Rex $v$. Jones was right in thinking that an exception ought to be made where there is a charge of murder) is that set out in rule 3. This rule is in form permissive. So of course is the rule relating to joinder in civil cases. . . . Both must, in my opinion, be read subject to the principle ... that "the court requires the parties to that litigation to bring forward their whole case, and will not (except under special circumstances) permit the same parties to open the same subject of litigation in respect of matter whicli might have been brought forward as part of the subject in contest." . . T The result of this will, I think, be as follows. As a general rule a judge should stay an indictment (that is, order that it remain on the file not to be proceeded with) when he is satisfied that the charges therein are founded on the same facts as the charges in a previous indictment on which the accused lias been tried, or form or are a part of a series of offences of the same or a similar character as the offences charged in the previous indictment. ${ }^{19}$

would not be possible to say that one is nearer than the other to the correct. Apart from human fallibility the differences may be accounted for by differences in the evidence. No systern of justice can guarantee that every judgment is right, but it can and should do its best to secure that there are not conflicting judgments in the same inatter. Suppose that in the present case the appellant had first been acquitted of robbery and then convicted of murder. Inevitably doubts would be felt about the soundness of the conviction. That is why every system of justice is bound to insist upon the finality of the judgment arrived at by a due process of law. It is quite inconsistent with that principle that the Crown should be entitled to re-open again and again what is in effect the same matter. [1964] A.C. at 1353. Cf. F. KAFRA, THE TRIAL 177-79 (rev. definitive ed., reprint 1968) (Eng. transl.).

19. [1964] A.C. at $1356-60$. 
The English court thus solved the problem of repeated trials by importing into the criminal law that portion of the civil doctrine of res judicata that requires joinder of related claims. Our Supreme Court solved the narrow problem that confronted it in the Ashe case by importing into the fifth amendment that aspect of the civil doctrine of res judicata known as collateral estoppel. The question that remains is whether our Supreme Court will take the further step and hold that the compulsory joinder aspect of the civil doctrine of res judicata is included in the fifth amendment guarantee against double jeopardy. That question cannot, in my opinion, be avoided inuch longer.

Rule 8 of the Federal Rules of Criminal Procedure provides for permissive joinder of criminal offenses. ${ }^{20}$ The American Law Institute's Model Penal Code incorporates a compulsory joinder provision which substantially embodies the "same transaction" requirement. ${ }^{21}$ The American Bar Association's recent Minimum Standards for Criminal Justice Relating to Joinder and Severance similarly provide for compulsory joimder of related offenses that "are based upon the same conduct or arise from the same criminal episode."22 In neither of these deliberate determinations was any serious inconvenience to the prosecution visualized. Each contains provisions for severance, and safeguards to cover exceptional circuinstances. But in the ordinary case each requires compulsory joinder, which means that those related offenses which are omitted from the first prosecution may not thereafter be the subject of another prosecution. When the Supreme Court confronts the issue it will do so against the background of the compulsory joinder provisions that have been considered necessary by the American Law Institute and the American Bar Association, and in the light of the recent decision of the House of Lords as to the scope of the present day common law protection against double jeopardy.

Let me now turn to an aspect of the double jeopardy problem suggested by Waller $v$. Florida. ${ }^{23}$ The question arises whether the concept of dual sovereignty is not an anachromism in the state-federal context as well as in the municipality-state context. That theory purports to justify successive state and federal prosecutions for the same act on the ground that the two jurisdictions are separate sovereign entities, each having a separate interest which it is entitled to vindicate.

The semmal cases in the field are Bartkus v. Illinois $^{24}$ and Abbate

20. FED. R. CRIM. P. 8.

21. Model Penal Code $\$ \S 107(2), 1.09$ (1)(b) (Proposed Official Draft, 1962).

22. ABA Minimum Standards for Criminal Justice, Joinder and Severance

1.1, 1.3 (Approved Draft, 1968).

23. 397 U.S. 387 (1970).

24. 359 U.S. 121 (1959). 
v. United States, ${ }^{25}$ both decided in 1959 , before the fifth amendment right against double jeopardy was held applicable to the states. In Bartkus, the defendant was first tried in a federal court for the offense of robbing a federally insured bank in Illinois. He was acquitted. Subsequently, he was tried in a state court on a charge of armed robbery (as well as on a second count under the Habitual Criminal Act) ${ }^{26}$ arising out of the same transaction. This time he was convicted. He was sentenced to 25 years on the robbery count and to life imprisonment under the Habitual Criminal statute. In a 5-4 decision the Supreme Court held that the defendant had not been deprived of due process of law. Justice Frankfurter's opimion for the majority stressed what he referred to as "a long, unbroken, unquestioned course of impressive adjudication" which rejected constitutional challenges to successive state and federal prosecutions based on the same conduct. ${ }^{27} \mathrm{He}$ also rehed heavily upon the practical needs of our federal system. The thought was that if the federal prosecution of a comparatively minor offense were to prevent subsequent state prosecution of a grave infraction of state law, "the result would be a shocking and untoward deprivation of the historic right and obligation of the States to mamtain peace and order within their confines. It would be in derogation of our federal system to displace the reserved power of States over state offenses by reason of prosecution of minor federal offenses by federal authorities beyond the control of the States."28 Justice Frankfurter illustrated this concern by referring to the situation in which a prosecution for violation of federal civil rights laws carrying maximum penalties of a year or two might be held to bar a subsequent state prosecution for murder. ${ }^{29} \mathrm{He}$ also pointed out that in the case before him Illinois had "an additional and unique interest" because of the defendant's habitual criminal status. ${ }^{30}$

In Abbate, the defendants allegedly conspired to dynamite some telephone company facilities. They were first tried and convicted in a state court on pleas of guilty to a charge of conspiring to injure or destroy the property of another in violation of state law. They were then tried in federal court on a charge of conspiring to injure or destroy cominunication facilities "operated or controlled by the United States." ${ }^{11}$ They were again convicted, and were sentenced to imprisonment. The Court held that the federal prosecution did not twice put the defendants

25. 359 U.S. 187 (1959).

26. Law of June 23,1883 , ch. $38, \S 602$ [1883] Ill. Laws $76 \S 1$ (repealed 1963).

27. 359 U.S. at 136 .

28. 359 U.S. at 137 .

29. 359 U.S. at 137, citing Screws v. United States, 325 U.S. 91 (1945).

30. 359 U.S. at $137, \mathrm{n} .25$.

31. 18 U.S.C. $\$ 1362$ (1967). 
in jeopardy for the same offense in violation of the fifth amendment. Justice Brennan, writing for a 6-3 majority, reiterated the fear that "if the States are free to prosecute criminal acts violating their laws, and the resultant state prosecutions bar federal prosecutions based on the same acts, federal law enforcement must necessarily be hindered. For example, the petitioners in this case insist that their Illinois convictions resulting in three months' prison sentences should bar this federal prosecution which could result in a sentence of up to five years. Such a disparity will very often arise when, as in this case, the defendants' acts impinge more seriously on a federal interest than on a state interest.".32

Both cases have been subjected to severe criticism by judges and legal scholars. ${ }^{33}$ Justice Black, dissenting in Bartkus, emphasized the historic purpose of the double jeopardy clause to protect the individual agamst the harassment of multiple trials for the same conduct:

If double punishment is what is feared, it hurts no less for two 'Sovereigns' to inflict it than for one. If danger to the innocent is emphasized, that danger is surely no less when the power of State and Federal Governments is brought to bear on one man in two trials, than when one of these 'Sovereigns' proceeds alone. ${ }^{34}$

In answer to Justice Frankfurter's reliance on federalism, he argued:

If the States were to subvert federal laws in these areas [of concurrent jurisdiction] by imposing inadequate penalties, Congress would have full power to protect the national interest, either by defining the crime to be punished and establishing minimum penalties applicable in both state and federal courts, or by excluding the States altogether..$^{35}$

A number of commentators have suggested that the authority rehed on by the Court in Bartkus and Abbate was unsatisfactory or inconclusive. $^{36}$ Apart from that consideration, the theory which permits inultiple prosecutions by state and nation is imconsistent with the principle of international law whereby a plea of autrefois acquit or autre fois convict will bar prosecution in one country after a defendant has already been tried for the same offense in another country properly

32. 359 U.S. at 195.

33. Pontikes, Dual Sovereignty and Double Jeopardy: A Critique of Bartkus v. Illinois and Abbate v. United States, 14 W. REs. L. REv. 700 (1963); Franck, $A n$ International Lawyer Looks at the Bartkus Rule, 34 N.Y.U.L. Rev. 1096 (1959); Note, 80 HaRv. L. Rev. 1538 (1967); Note, 44 MinN. L. Rev. 534 (1960); Note, 45 CorNell L.Q. 574 (1960). See also Grant, Successive Prosecutions by State and Nation: Common Law and British Empire Comparisons, 4 U.C.L.A.L. REv. 1 (1956).

34. Bartkus v. Illinois, 359 U.S. 121, 155 (1959) (Black, J., dissenting).

35. 359 U.S. at 157 (Black, J., dissenting).

36. See Pontikes, supra note 33 at 706-11; Grant, supra note 33, at 4-5; Note, 80 HARv. L. Rev. 1538, 1541-42 (1967); Note, 45 CORNell L.Q. 574, 576 (1960). 
exercising concurrent jurisdiction. ${ }^{37}$ The Supreme Court of the United States long ago recognized this principle in a case involving the exercise of concurrent jurisdiction over pirates on the high seas. ${ }^{38}$ Said the Court: "there can be no doubt that the plea of autrefois acquit would be good, in any civilized state, though resting on a prosecution instituted in the courts of any other civilized state." ${ }^{\text {s }}$

In addition, there are two decisions of the Supreme Court in different, but related, areas of the criminal law, which represent a departure froin the dual sovereignty doctrine. ${ }^{40}$ One is Murphy $v$. Waterfront Commission, ${ }^{41}$ decided in 1964, in which the Court held that a state nray not compel a witness to give testimony which might be used against him in a subsequent federal prosecution. In so holding the Court rejected the notions that the state and federal governments were "separate and distinct sovereignties, acting separately and independently of each other, within their respective spheres," ${ }^{\prime 2}$ and that it would be an intolerable interference if one sovereign could immunize a witness against the use of testimony by another. The Court recognized that most of the policies and purposes behind the privilege against self-incrimination "are defeated when a witness 'can be whipsawed into incriminating himself under both state and federal law even though' the constitutional privilege ... is applicable to each. ... This has become especially true in our age of 'cooperative federalism,' where the federal and state governments are waging a united front against inany types of criminal activity." +3

The other case which exhibits a departure from the dual sovereignty concept is Elkins $v$. United States, ${ }^{44}$ decided in 1960, in which the Court overturned the so-called "silver-platter doctrine" under which evidence obtained as the result of an unreasonable search and seizure by state officers, without federal participation, could be introduced against a defendant in a federal criminal trial. The "silver-platter doctrine" also had its underpinnings in the dual sovereignty theory: federal law enforcement activities should not be hampered by unregnlable blunders of state law enforcement officials. In overturning the doctrine, Justice Stewart, writing for the Court, recognized the growing

37. See Franck, supra note 33, at 1098-99.

38. United States v. Furlong, 18 U.S. 86, 5 Wheat. 184 (1820).

39. Id. at 97,5 Wheat. at 195.

40. See Note, Double Prosecution by State and Federal Governments: Another Exercise in Federalism, 80 HARv. L. REv. 1538, 1544-49 (1967).

41. 378 U.S. 52 (1964).

42. Feldman v. Unitcd States, 322 U.S. 487, 491 (1944), quoting with approval Ableman v. Booth, 62 U.S. (21 How.) 506, 516 (1858). See also United States v. Murdock, 284 U.S. 141 (1931).

43. 378 U.S. at 55-56.

44. 364 U.S. $206(1960)$. 
and "entirely commendable practice of state and federal agents to cooperate with each other in the investigation and detection of criminal activity." $\mathrm{He}$ also einphasized the defendant's point of view rather than the institutional needs of federalism: "To the victim it matters not whether his constitutional right has been invaded by a federal agent or by a state officer." 46

The close division of the Supreme Court in Bartkus and Abbate, coupled with the subsequent decision in Benton v. Maryland, ${ }^{47}$ which extended the protection against double jeopardy to state court actions, requires us to anticipate that the two sovereignties rule may be abandoned. If it is, then we would at least expect to see the doctrine of collateral estoppel, which the Court applied to the reprosecution in Ashe v. Swenson, applied to successive state-federal and federal-state prosecutions. As has been pointed out, collateral estoppel has obvious limitations. Nevertheless, the Ashe approach would have a measurable effect not only in cases like Bartkus, where the state and federal laws deal with what is essentially the same offense, but in those cases in which the state and federal statutes, although substantially different with respect to the type and importance of the interest to be protected, and the severity of the sanction, nevertheless require proof of some common evidentiary element.

We do not yet know how the Supreme Court will treat the converse of the Ashe situation-where the initial prosecution results in a conviction. In Ashe the Court failed to adopt a proposal by Justice Brennan that a "single transaction" test be adopted in judging the permissibility of successive prosecutions. Such a test would resolve the problein presented by a prior conviction and, given provisions for joinder of related offenses, it would create no serious difficulties where the successive prosecutions take place within the same jurisdiction. Should it be held apphicable to reprosecutions by different jurisdictions, however, the possibility of state-federal collision would presumably be increased. ${ }^{48}$

One example adverted to is the converse of the situation referred to by Justice Frankfurter in Bartkus-the risk that a state court might be able to preclude the federal government from protecting persons against intimidation or violence in the exercise of their civil rights by an anticipatory prosecution resulting either in an acquittal or the imposition of nommal penalties. Although such a deliberate attempt to immunize a defendant inay be relatively unlikely, one must recognize that

45. 364 U.S. at 211.

46. 364 U.S. at 215 (footnote omitted).

47. 395 U.S. 784 (1969).

48. See Note, 80 HARv. L. REv. $1538,1559-60$. 
there are many areas, particularly those involving interstate commerce, where state and federal laws do have a considerable overlap, and that a state or federal prosecution which would otherwise be available could be foreclosed. Examples may be found or hypothesized in the obstruction of interstate commerce by an act of robbery, the perpetration of fraud through the use of the mails, and so on. In some situations it might fairly be concluded, however, as I would now feel with respect to Bartkus, that the basic objectives of both the state and federal acts were the same, and that the interest of each jurisdiction would be adequately vindicated even though the prosecution had been conducted by the other. In other situations, however, it may be that the two offenses to which the unitary conduct of the defendant gave rise did indeed relate to quite dissimilar concerns of the two jurisdictions involved. ${ }^{49}$

Even so, it seems to me that a workable adjustment between competing claims of the states and the federal government can be achieved, although it may be that new legislation is needed. Some legislative provisions already exist which are addressed to this problem. A number of states have enacted provisions prohibiting, at least to some degree, prosecution of one who has previously been acquitted or convicted in another jurisdiction for the same conduct. ${ }^{50}$ Federal law, on the other hand, although lacking any such blanket prohibition, does include a number of statutes in which the right to prosecute has been relinquished in the event that acquittal or conviction "for the same act" has already occurred under the auspices of state law, for example the theft of goods from an interstate shipment. ${ }^{51}$

So far as the federal government is concerned, its interests could always be protected by a legislative preemption of the field. ${ }^{52} \mathrm{~A}$ fortiori, the government could validly provide for the suspension of state proceedings pending federal decision whether to prosecute (as has been done in the law concerning presidential assassinations), together with provision for notification by state authorities of indictunents for offenses which also constitute a violation of federal law. Other solutions which have been suggested include authorizing state courts to try federal offenses or, conversely, authorizing federal trial of state charges where a federal offense is also involved..$^{53}$ One writer has proposed that a person charged by the state be given an election to be tried instead un-

49. See id. at 1561-63.

50. See, e.g., CaL. Penal Code $\$ 656$ (West 1955). For a list of other state statutes, see Harrison, Federalism and Double Jeopardy: A Study in the Frustration of Human Rights, 17 U. Mrami L. REv. 306, 342, n.190 (1963).

51. 18 U.S.C. § 2117 (1967).

52. See Bartkus v. Illinois, 359 U.S. 121, 157 (1959) (Black, J., dissenting).

53. See 80 HARV. L. REv. 1538, 1554, n.108. 
der federal law if the latter covers the same ground. ${ }^{54}$ Under this plan if a federal trial is opted for, and if the federal government agrees to institute it, the judgment in the federal proceeding would be conclusive and final. Conversely, if the federal government declined to proceed, the matter would go forward in the state court and no federal prosecution would be subsequently allowed. Were the defendant to elect trial by the state, however, the judgment rendered in that proceeding would not preclude a federal reprosecution as to the federal issues involved. Still another proposal-a kind of criminal interpleader -would permit a person charged in one jurisdiction, by giving suitable notice, to require other jurisdictions with a right to prosecute to forego such right unless they were prepared to participate with the "primary jurisdiction" in a joint trial. ${ }^{55}$

Whether the abolition of the two sovereignties doctrine would in reality threaten substantial impairment of the respective interests of state and federal government in law enforceinent is a matter on which opinions necessarily differ at this stage of history. For myself, I suspect that the area of overlap is not quantitatively a major one, and that administrative cooperation between the federal and state enforcement agencies could be effective in reaching a practical accommodation in those cases where overlap exists. The various legislative solutions mentioned above may have certain legal and practical hinitations, and I express no opinion as to their relative merits. Collectively, however, they indieate to ine that to the extent that informal cooperation should prove inadequate, there is a range of legislative devices which inay be brought to bear on inost, if not all, of the problein areas.

54. See Fisher, Double Jeopardy and Federalism, 50 MinN. L. Rev, 607, 610-13 (1966).

55. See Newman, Double Jeopardy and the Problem of Successive Prosecutions: A Suggested Solution, 34 S. CaL. L. Rev. 252, 266-67 (1961). 